\title{
APLIKASI SISTEM INFORMASI SEWA KAMAR PADA CV SURYAKOST BERBASIS ANDROID
}

\author{
Niko Prayoga Wiratama ${ }^{1}$, Rudi Prasetya ${ }^{2}$, Gita Kencanawaty ${ }^{3}$ \\ Program Studi Teknik Informatika, Fakultas Teknik dan Ilmu Komputer, \\ Universitas Indraprasta PGRI \\ Jalan Raya Tengah No 80, Kelurahan Gedong, Pasar Rebo, Jakarta Timur \\ Nikx449@gmail.com ${ }^{1}$,rudiprasetya1@gmail.com², gitakencawaty@gmail.com ${ }^{3}$
}

\begin{abstract}
Abstrak
Penyewaan kamar merupakan salah satu alternatif untuk orang-orang yang ingin bekerja atau kuliah di suatu daerah tetapi jauh dari tempat tinggalnya. Mereka yang ingin mencari tempat tinggal sementara pasti akan memilih tempat penyewaan kamar yang dekat dengan lokasi kerja atau kuliahnya. Dengan dilengkapi fasilitas bagus, lokasi yang strategis, dan harga yang terjangkau. CV Suryakost merupakan salah satu tempat penyewaan kamar yang memiliki fasilitas lengkap dengan harga terjangkau. Tetapi cara kerja sistem yang digunakan CV Suryakost masih manual, sehingga terdapat beberapa kendala dalam melakukan proses penyewaan kamar. Beberapa cara dalam meningkatkan pelayanan dan fasilitas, salah satunya adalah dengan memberikan informasi yang cepat dalam melakukan pemesanan kamar kepada pengunjung. Perancangan aplikasi ini bertujuan untuk membantu dan mempermudah CV Suryakost dalam pelayanan dan peningkatan fasilitas penyewaan kamar. Dengan membangun sebuah system yang mengadopsi teknologi informasi, dapat mempermudah pemesanan dan pembayaran sewa kamar setiap bulan secara daring. Metode penelitian ini menggunakan metode Research and Development (R\&D). Aplikasi ini nantinya akan berguna untuk memfasilitasi pengunjung pada saat menyewa kamar, begitu juga dengan CV Suryakost dapat lebih mudah memantau para pengunjung dalam melakukan transaksi dan pemesanan kamar.
\end{abstract}

Kata Kunci: Android, Firebase, Reservasi, Sewa Kamar, Sistem

\begin{abstract}
Room rentals are an alternative for people who want to work or study in an area but are far from where they live. Those who want to find temporary accommodation will definitely choose a room to rent a room close to their work or college location. Equipped with good facilities, strategic location, and affordable prices. CV Suryakost is a room rental place that has complete facilities at affordable prices. But the way the system used by CV Suryakost is still manual, so there are several obstacles in the process of renting a room. There are several ways to improve services and facilities, one of which is by providing fast information in making room bookings to visitors. The design of this application aims to assist and simplify CV Suryakost in providing services and improving room rental facilities. By building a system that adopts information technology, it can make it easier to order and pay room rent every month online. This research method uses the Research and Development $(R \& D)$ method. This application will later be useful to facilitate visitors when renting a room, as well as $C V$ Suryakost can more easily monitor visitors in making transactions and booking rooms. This research method uses the Research and Development $(R \& D)$ method. This application will later be useful to facilitate visitors when renting a room, as well as $C V$ Suryakost can more easily monitor visitors in making transactions and booking rooms. This research method uses the Research and Development $(R \& D)$ method. This application will later be useful to facilitate visitors when renting a room, as well as CV Suryakost can more easily monitor visitors in making transactions and booking rooms.
\end{abstract}

Keywords: Android, Firebase, Rent Room, Reservation, System

\section{PENDAHULUAN}

Perkembangan teknologi di era globalisasi ini semakin cepat dan canggih. Kemajuan yang memberikan banyak manfaat dalam kehidupan, diantaranya adalah komputer, internet dan alat telekomunikasi yang memudahkan interaksi manusia satu sama lain tanpa adanya hambatan jarak. Dengan penggunaan teknologi informasi dapat mempercepat proses pengolahan data menjadi informasi. 
Sewa adalah pemakaian sesuatu dengan membayar uang atau uang yang dibayarkan karena memakai atau meminjam sesuatu. Penghasilan yang diterima atau diperoleh sehubungan dengan kesepakatan untuk memberikan hak menggunakan harta selain tanah dan atau bangunan selama jangka waktu tertentu baik dengan perjanjian tertulis maupun tidak tertulis sehingga harta tersebut hanya dapat digunakan oleh penerima hak selama jangka waktu yang telah disepakati (Sunarto, 2016).

CV Suryakost yang berada di Serpong merupakan tempat penyewaan kamar dengan memiliki fasilitas yang lengkap dan ketersediaan kamar yang banyak, tetapi sistem penyewaan kamar di CV Suryakost masih menggunakan cara manual. Untuk reservasi kamar, pengunjung harus datang ke tempat terlebih dahulu.

Proses reservasi kamar, pemesanan kamar, dan pembayaran sewa di CV Suryakost selama ini berjalan menggunakan sistem manual yang menghabiskan banyak waktu dan tenaga. Karena banyaknya permintaan untuk reservasi dan pemesanan kamar serta pembayaran sewa setiap bulan. Penggunaan platform android untuk CV Suryakost dapat memudahkan proses penyewaan kamar, karena informasi tentang kamar yang ingin dipesan sudah tersedia di dalam aplikasi dan tanggal pemesanan serta jenis kamar yang tersedia. Jadi, pengunjung tidak perlu datang terlebih dahulu untuk memastikan ketersediaan dan fasilitas kamar.

Sistem menurut Jogiyanto sebagai suatu kesatuan yang terdiri dari dua atau lebih komponen atau subsistem yang berinteraksi untuk menegaskan suatu tujuan (Mujiati \& Sukadi, 2014). Sistem penyewaan kamar ini dibuat agar pengunjung dapat mengetahui fasilitas dan ketersedian kamar dengan mudah serta mendapat rincian mengenai biaya sewa yang tepat, lalu memudahkan perusahaan dalam mengolah reservasi kamar, jenis kamar yang tersedia, pemesanan kamar, dan pembayaran sewa tiap bulan. Sehingga diharapkan dengan adanya sistem penyewaan kamar di CV Suryakost berbasis android dapat meningkatkan pemasukan bagi CV Suryakost serta pelayanan terhadap pengunjung.

\section{PENELITIAN RELEVAN}

Penelitian oleh Dhedek Dono Widodo (2016) dengan judul Sistem Reservasi Hotel Di Kota Pacitan Berbasis Android. Tujuan dari penelitian ini adalah untuk mengatasi masalah sistem reservasi, data pemesanan dan data pengunjung hotel di kota Pacitan yang masih manual dan mengharuskan para wisatawan untuk mendatangi hotel untuk melakukan reservasi. Dengan adanya sistem reservasi hotel ini para wisatawan dan juga pengunjung hotel dapat melakukan reservasi lewat smartphone dan juga ada sistem GPS (Global Positioning System) yang memudahkan para wisatawan menuju hotel tersebut (Widodo, 2016).

Penelitian oleh Ari Prabowo dan Endang Retnoningsih (2017) dengan judul Sistem Informasi Reservasi Kamar Hotel Pada Hotel Posters MICE. Tujuan dari penelitian ini adalah untuk mengatasi masalah pemesanan kamar hotel yang masih mengalami kendala dan tidak tersedianya aplikasi yang dapat mampu menampung serta mengolah data pemesanan kamar. Sistem informasi reservasi ini merupakan sebuah aplikasi yang dapat membantu mempercepat pendaftaran atau registrasi saat di bagian resepsionis. Pembatalan pun dapat langsung di kelola oleh admin atau resepsionis. Sehingga memberikan kemudahan lain dalam melakukan pemesanan. (Prabowo \& Retnoningsih, 2017).

\section{METODE PENELITIAN}

Metode pengembangan atau Research and Development $(R \& D)$ adalah metode yang digunakan dalam penelitian ini. Metode penelitian $R \& D$ adalah metode penelitian yang digunakan untuk menghasilkan produk tertentu, dan menguji efektifitas produk tersebut dengan suatu proses atau langkah-langkah untuk mengembangkan suatu produk baru atau menyempurnakan produk yang telah ada (Sugiyono, 2011:333). Dengan menggunakan metode ini maka dilakukan penelitian secara langsung pada CV Suryakost sesuai pada pokok permasalahan yang diteliti.

Dalam pengembangan sistem peneliti menggunakan metode Waterfall. Metode Waterfall sering dinamakan siklus hidup klasik (Classic Life Cycle), metode Waterfall dimulai dengan spesifikasi kebutuhan pengguna lalu berlanjut melalui tahapan-tahapan Perencanaan (Planning), Permodelan (Modeling), Konstruksi (Construction), serta penyerahan sistem ke para Pengembang 
(Deployment), yang diakhiri dengan dukungan pada perangkat lunak lengkap yang dihasilkan (Hays et al., 2018).

Dalam pengembangannya metode Waterfall memiliki beberapa tahapan yang berurut yaitu Requirement Analysis (Analisis Kebutuhan), System Design (Desain Sistem), Implementation (Implementasi), Integration (Pengintegrasian) \& Testing (Pengujian), Operation (Pengoperasian) \& Maintenance (Pemeliharaan). Tahapan tahapan dari metode Waterfall adalah sebagai berikut:

a. Requirement Analysis

Tahap ini pengembang sistem diperlukan komunikasi yang bertujuan untuk memahami perangkat lunak (Software) yang diharapkan oleh pengguna dan batasan perangkat lunak tersebut. Informasi ini biasanya dapat diperoleh melalui wawancara, diskusi atau survei langsung. Informasi dianalisis untuk mendapatkan data yang dibutuhkan oleh pengguna atau biasa disebut user (Amin et al., 2018).

b. System Design

Desain Sistem ini dilakukan sebelum melakukan coding. Tahap ini bertujuan untuk memberikan gambaran apa yang haru dikerjakan dan bagaimana tampilan yang akan dibuat. Tahap ini dapat membantu dalam menspesifikasikan kebutuhan hardware dan sistem serta mendefinisikan arsitektur sistem secara keseluruhan (Safitri \& Supriyadi, 2015).

c. Implementation

Pada tahap ini, sistem pertama kali dikembangkan di program kecil yang disebut unit, yang terintegrasi dalam tahap selanjutnya. Setiap unit dikembangkan dan diuji untuk fungsionalitas yang disebut sebagai unit testing (Amin et al., 2018).

d. Integration \& Testing

Dalam tahapan ini, setiap unit program akan diintegrasi satu sama lain dan diuji sebagai satu sistem yang utuh untuk memastikan sistem sudah memenuhi persyaratan yang ada. Setelah itu sistem akan dikirim ke pengguna sistem (Fatmawati \& Munajat, 2018).

e. Operation \& Maintenance

Dalam tahapan ini, sistem dipasang dan mulai digunakan. Selain itu juga memperbaiki galat yang tidak ditemukan pada tahap pembuatan. Dalam tahap ini juga dilakukan pengembangan sistem seperti penambahan fitur dan fungsi baru (Sommerville, 2011).

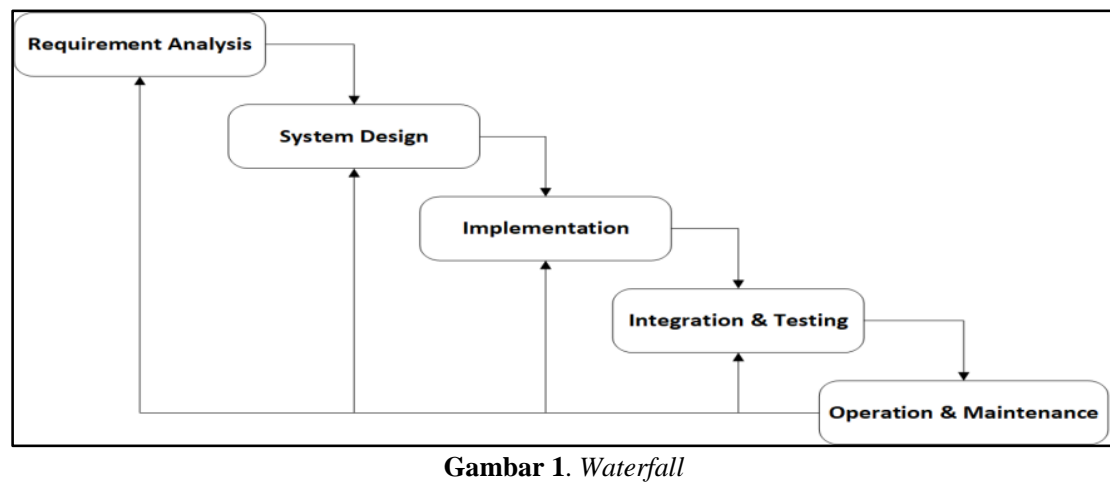

Dalam metode pengumpulan data yang dilakukan oleh peneliti untuk mendapatkan data-data serta informasi yang mendukung penyempurnaan hasil dari penelitian ini antara lain:

a. Observasi

Peneliti mengadakan kunjungan langsung ke CV Suryakost untuk memperoleh data secara akurat dan memperoleh gambaran sistem berjalan yang tepat.

b. Wawancara

Metode wawancara sangat diperlukan untuk proses penelitian ini, guna memperoleh informasi yang akurat. Peneliti melakukan tanya jawab langsung kepada narasumber diantaranya pemilik, karyawan, maupun pihak lain yang berkaitan langsung dalam penyewaan kamar.

c. Kepustakaan

Peneliti juga melakukan studi kepustakaan dengan menggunakan buku yang dapat dijadikan referensi dan juga internet, guna menunjang informasi yang dibutuhkan dalam penelitian ini. 


\section{HASIL DAN PEMBAHASAN}

\section{Analisa Permasalahan}

Berdasarkan dari hasil penelitian secara langsung sistem penyewaan kamar pada CV Suryakost, maka peneliti dapat menganalisa permasalahan yang terjadi yaitu:

1. Pengunjung harus datang ke tempat untuk reservasi kamar, yang berakibat memakan biaya bagi pengunjung hanya untuk reservasi.

2. Kesulitan pengunjung mendapatkan informasi tentang fasilitas dan ketersediaan kamar.

3. Tagihan sewa kamar sering tidak relevan karena proses penghitungan masih manual.

\section{Alternatif Penyelesaian Masalah}

Berdasarkan analisa permasalahan yang ada pada CV Suryakost dan masih menjadi permasalahan sampai dibuatnya penelitian ini, maka dari itu peneliti dapat menyarankan beberapa alternatif dalam menyelesaikan masalah tersebut antara lain:

1. Mempermudah pengunjung untuk melakukan reservasi tanpa harus datang ke tempat dengan menggunakan aplikasi android yang terhubung ke internet.

2. Memudahkan pengunjung dalam mendapatkan informasi tentang fasilitas dan ketersediaan kamar pada saat ingin memesan kamar melalui aplikasi android.

3. Tagihan sewa kamar konsisten dan tidak berubah-ubah karena sudah dengan perhitungan otomatis menggunakan komputasi.

Berikut merupakan Flowchart sistem sewa kamar yang diusulkan pada CV Suryakost:

\section{Flowchart Login}

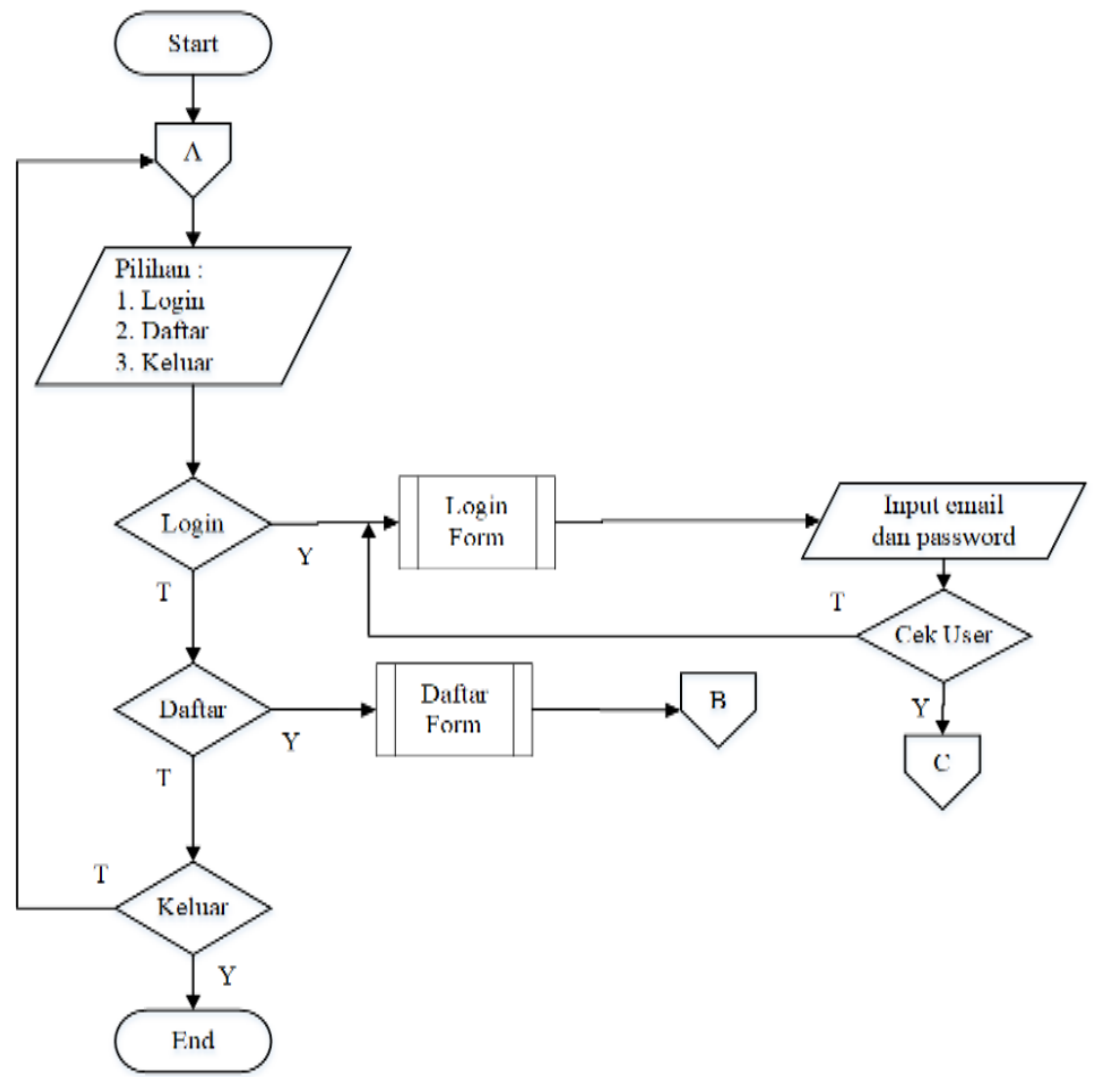

Gambar 2. Flowchart Login 


\section{Flowchart Pemesanan Kamar}

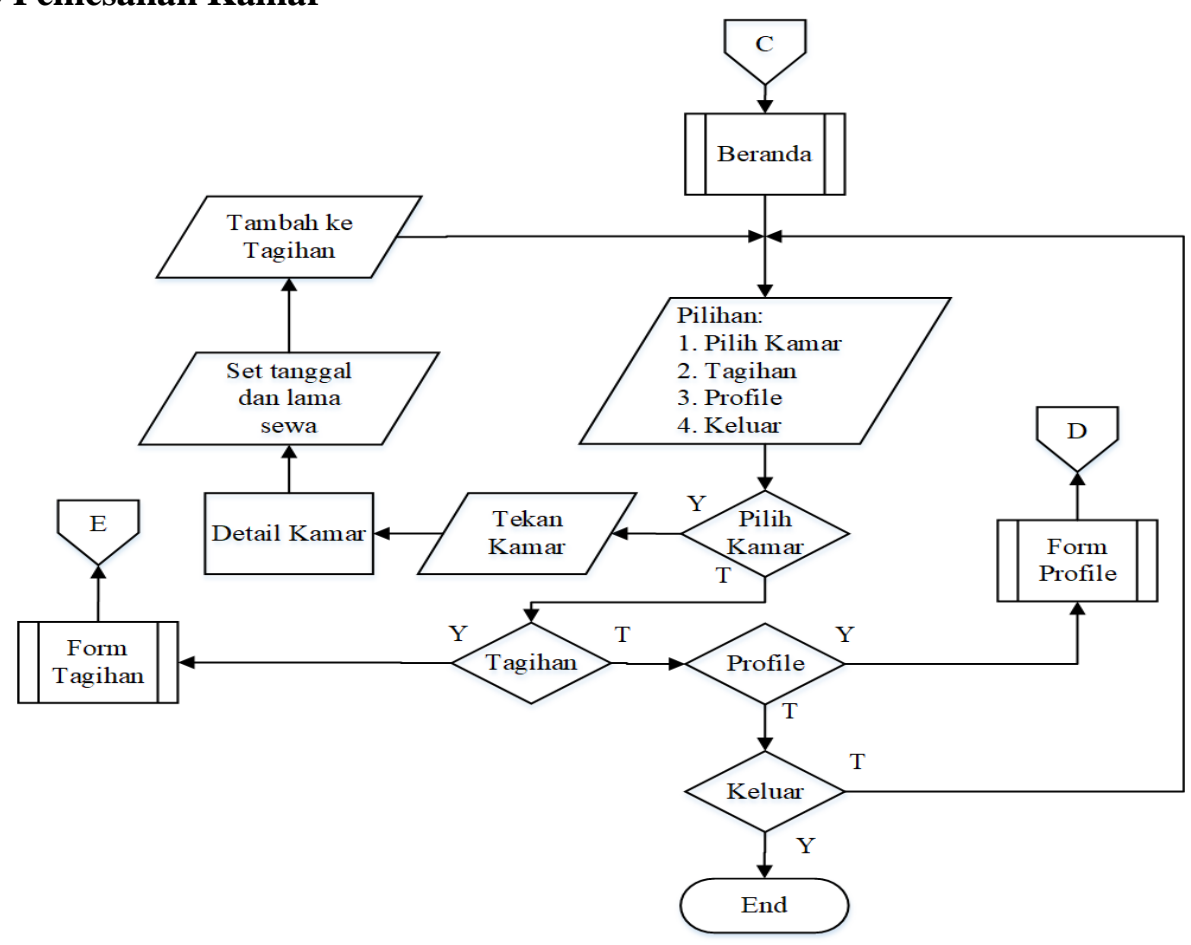

Gambar 3. Flowchart Pemesanan Kamar

\section{Flowchart Tagihan Pembayaran}

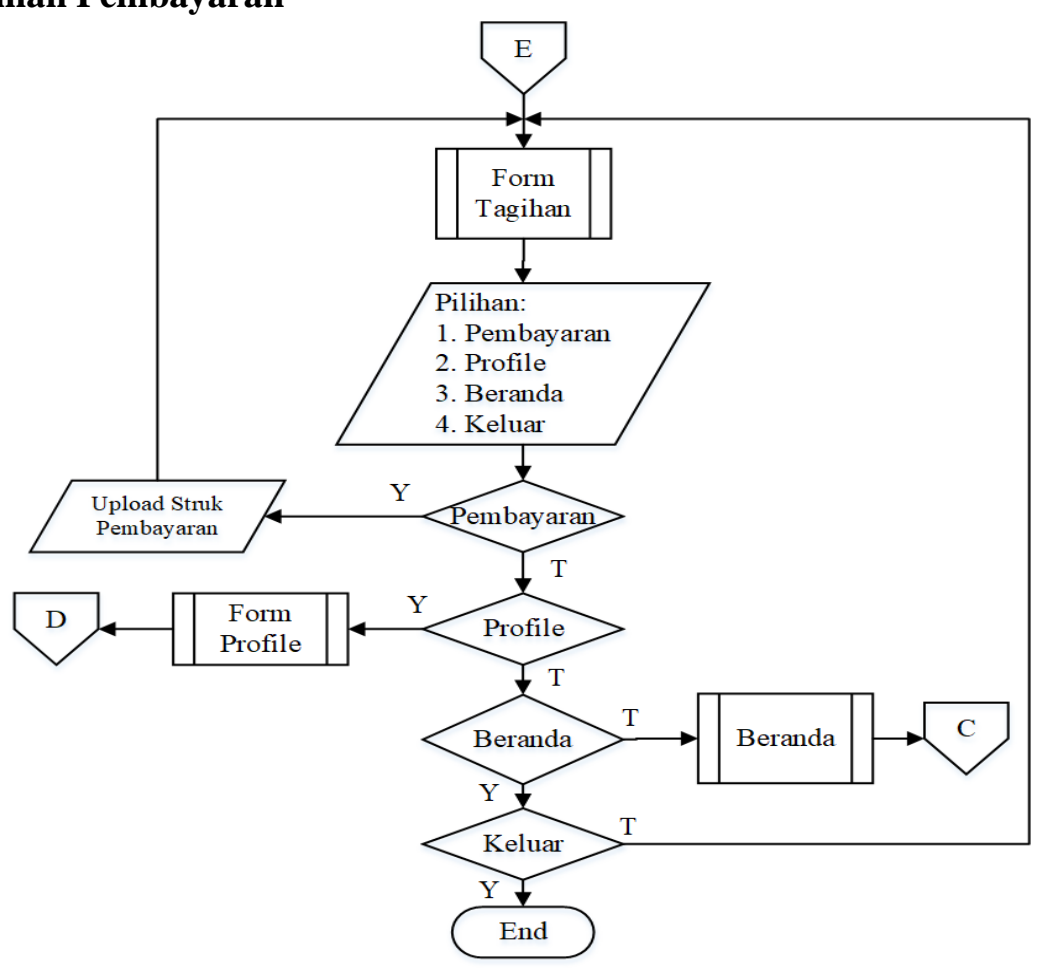

Gambar 4. Flowchart Tagihan Pembayaran 


\section{Tampilan Aplikasi}

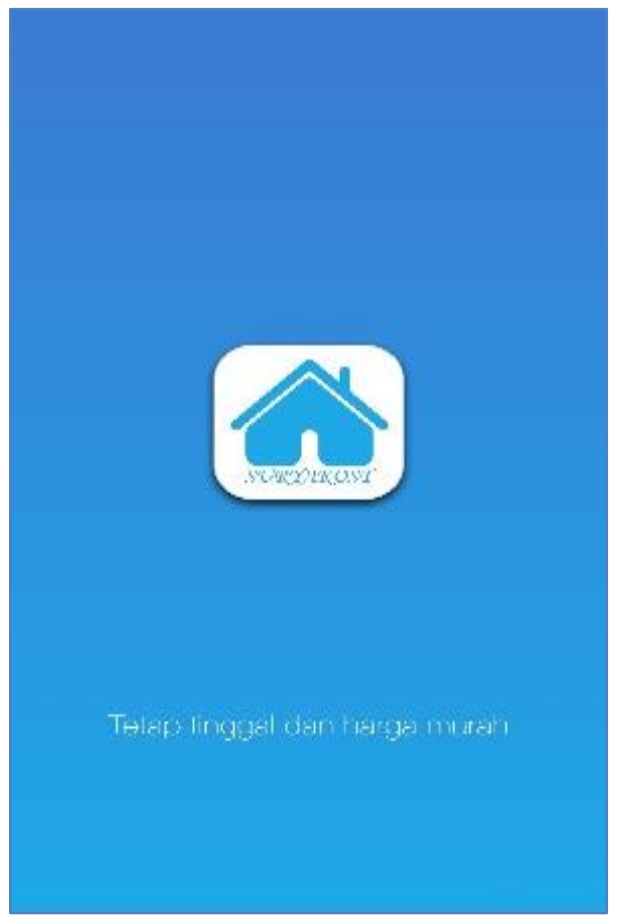

Gambar 5. Splash Screen

Pada Gambar 5 merupakan sebuah tampilan ketika pengunjung masuk kedalam aplikasi terdapat gambar logo.

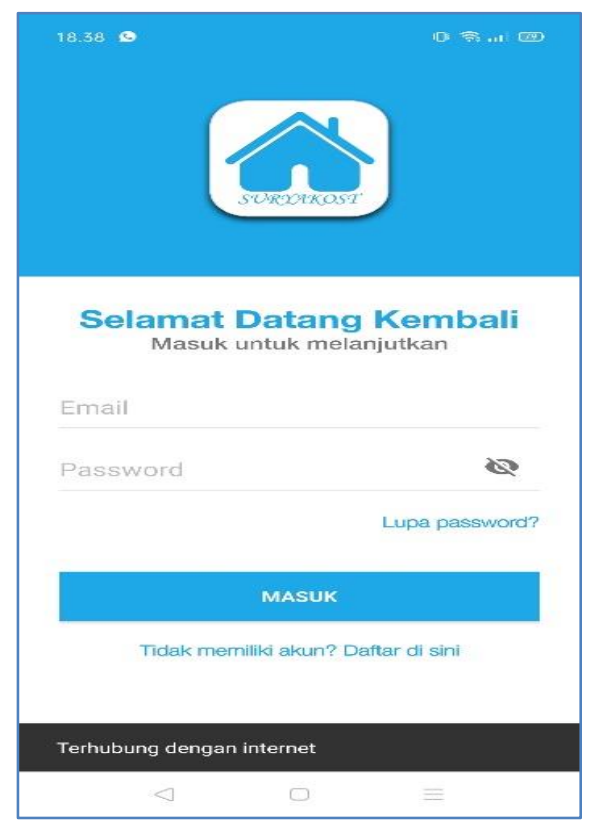

Gambar 6. Login Screen

Pada Gambar 6 terdapat tampilan daftar dan masuk dimana pengunjung yang belum mendaftar harus mengisi data diri di bagian daftar, untuk pengunjung yang sudah pernah mendaftar dapat memasukan email dan password di halaman masuk sebagai konfirmasi diri untuk masuk ke halaman utama. 


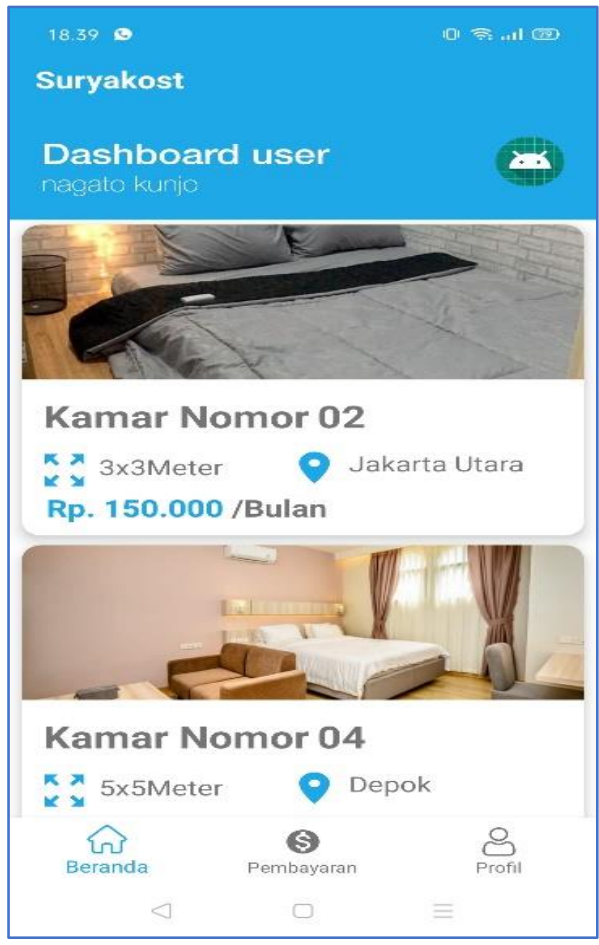

Gambar 7. Home Screen

Pada Gambar 7 terdapat tampilan kamar dan detail kamar dimana berisi berbagai jenis kamar yang disewa.

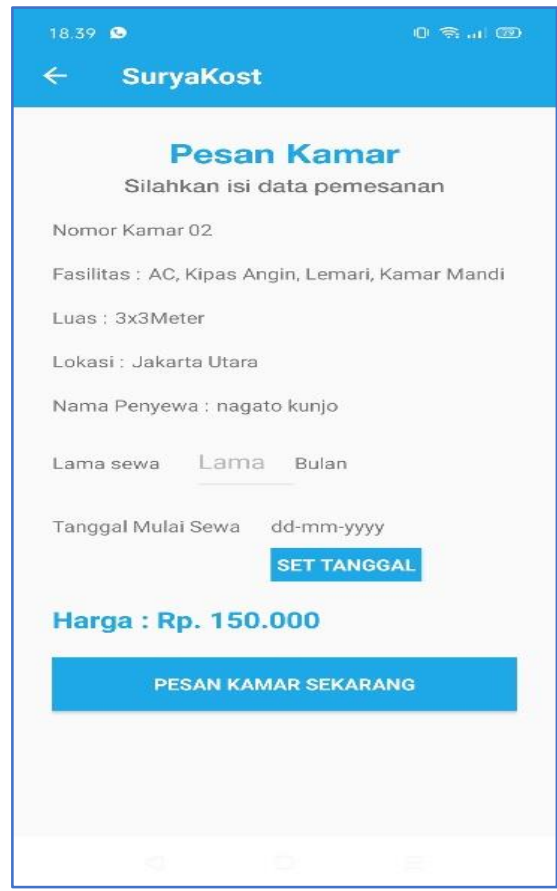

Gambar 8. Tampilan Pesan Kamar

Pada Gambar 8 merupakan tampilan pesan kamar dengan memasukkan lama sewa dan tanggal sewa kamar. Kemudian akan dimasukkan kedalam database. 


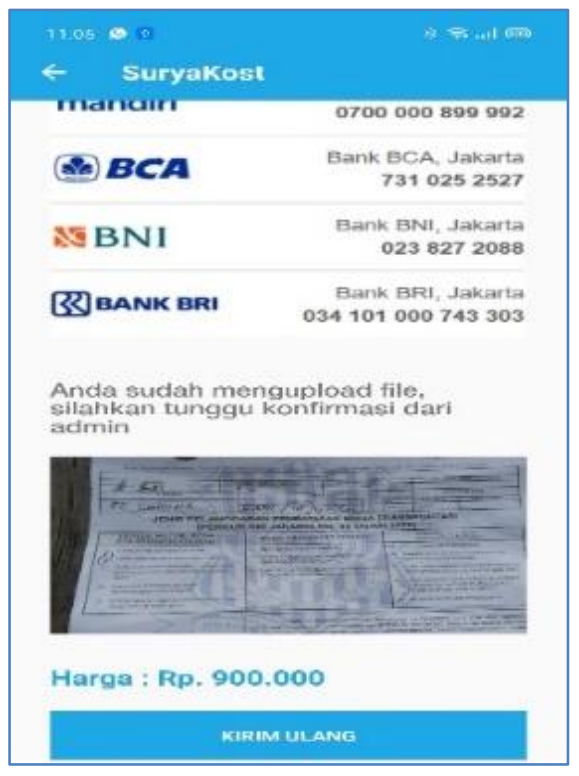

Gambar 9. Tampilan Tagihan Pembayaran

Pada Gambar 9 menampilkan tagihan untuk pembayaran sewa kamar setiap bulan dengan mengunggah struk bukti pembayaran sewa kamar.

\section{SIMPULAN}

Berdasarkan hasil dari pembahasan yang telah diuraikan sebelumnya dan menyesuaikan hasil dari Aplikasi Sistem Informasi Sewa Kamar Pada CV Suryakost Berbasis Android, maka kesimpulan yang diperoleh peneliti adalah sebagai berikut:

1. Dengan dibuatnya sistem aplikasi sewa kamar dapat memudahkan CV Suryakost dalam melayani proses pemesanan dan penyewaan kamar yang biasanya dilakukan dengan cara manual.

2. Dengan dibuatnya aplikasi sewa kamar dapat memudahkan pengunjung untuk melakukan reservasi kamar dengan fasilitas dan jenis kamar yang tersedia.

3. Memudahkan pengunjung dalam memesan kamar dengan tampilan yang interaktif, proses pemesanan yang mudah serta menampilkan rincian harga yang sesuai.

4. Memudahkan pengunjung dan admin dalam melakukan transaksi pembayaran sewa kamar.

\section{DAFTAR PUSTAKA}

Amin, A. I., Darmawan, E., \& Budianto, H. (2018). Implementasi CRM (Customer Relationship Management) pada Sistem Informasi Reservasi Fotografi berbasis Web di Toko Aini Photo Kuningan. Nuansa Informatika, 10(2), 19. https://doi.org/10.25134/nuansa.v10i2.991

Fatmawati, F., \& Munajat, J. (2018). Implementasi Model Waterfall Pada Sistem Informasi Persediaan Barang Berbasis Web (Studi Kasus: PT. Pamindo Tiga T). JURNAL MEDIA INFORMATIKA BUDIDARMA, 2(2), 1-9. http://dx.doi.org/10.30865/mib.v2i2.559

Hays, R. N., Sugiyarta, A., \& Winungkas, D. E. (2018). Aplikasi Inventory Terintegrasi Order System Konsumen Pada Oto Bento Perumnas Cilegon Menggunakan Metode Waterfall. ProTekInfo (Pengembangan Riset dan Observasi Teknik Informatika), 5, 22-25. https://doi.org/10.30656/protekinfo.v5i0.713

Mujiati, H., \& Sukadi. (2014). Sistem Informasi Dan Implementasinya Teori Dan Konsep Sistem Informasi Disertai Berbagai Contoh Pratiknya Menggunakan Perangkat Lunak Open Source. Indonesian Jurnal on Computer Science, 9330(2), 1-6. https://doi.org/10.3112/SPEED.V12I1.1281

Prabowo, A., \& Retnoningsih, E. (2017). Sistem Informasi Reservasi Kamar Hotel Pada Hotel Posters MICE. Jurnal Mahasiswa Bina Insani, 1(2), 147-160.

Safitri, S. T., \& Supriyadi, D. (2015). Rancang Bangun Sistem Informasi Praktek Kerja Lapangan Berbasis Web dengan Metode Waterfall. Jurnal Infotel, 7(1), 69-74. https://doi.org/10.20895/infotel.v7i1.32

Sugiyono. (2013). Metode Penelitian Kuanititatif, Kualitatif, Dan R\&D. Bandung: Penerbit Alfabet.

Sunarto, S. (2016). Sewa Menyewa Mobil Rental ditinjau dari Ekonomi Islam (Studi Kasus di Kecamatan Sario Kota Manado. Jurnal Ilmiah Al-Syir'ah, 12(1). http://dx.doi.org/10.30984/as.v12i1.277

Sommerville, Ian. 2011. Software Engineering. 9th Edition. America: Pearson. Education ,Inc.

Widodo, Dhedek Dono. (2016). SISTEM RESERVASI HOTEL DI KOTA PACITAN BERBASIS ANDROID (Doctoral dissertation, Universitas Muhammdiyah ponorogo). 